\title{
Rusmiddelbruk og dødelighet
}

\author{
Ingeborg Rossow
}

Statens institutt for alkohol- og narkotikaforskning, Dannevigsveien 10, 0463 Oslo

Telefon 223804 85, Telefax 2271 90 59, E-mail imr@sifa.no

\begin{abstract}
SAMMENDRAG
Bruk og misbruk av rusmidler øker risikoen for en tidlig død. Blant kroniske alkoholmisbrukere er overdødeligheten på omkring 2-3, og størst overdødelighet finner vi mht. levercirrhose, kreft i øvre deler av fordøyelseskanalen, selvmord og ulykker. Akutt beruselse har spesielt betydning for ulykkesdødsfall som drukning og trafikkulykker. Epidemiologiske studier har vist at moderat alkoholkonsum gir en redusert risiko for hjertekardødelighet sammenliknet med avholdenhet (en J-formet risikokurve). Disse funnene reiser en viktig debatt omkring implikasjonene for folkehelse.

På aggregert nivå gir en økning i alkoholkonsumet en beskjeden effekt på samlet dødelighet, men for alkoholrelaterte sykdommer, ulykker og selvmord ser man betydelige effekter av endringer i gjennomsnittskonsumet.

Stoffmisbrukere har en høyere overdødelighet enn alkoholmisbrukere (RR omkring 5-30), og de vanligste dødsårsakene er overdoser, selvmord og ulykker. Bruk og misbruk av alkohol er betydelig mer utbredt i befolkningen enn narkotika, og størstedelen av rusmiddelrelaterte dødsfall kan knyttes til alkohol. Det er imidlertid usikkert om dette gjenspeiles i opinionen og som argument ved politiske beslutninger og ressursallokeringer.
\end{abstract}

Rossow I. Alcohol, drugs and mortality. Nor J Epidemiol 1996; 6 (1): 37-44.

\section{ENGLISH SUMMARY}

Use and abuse of intoxicants increase the risk of premature death. Among chronic alcohol abusers the excess mortality is in the range of 2-3. Tthe highest excess mortality is found with respect to liver cirrhosis, cancer in the upper digestive tract, suicide and accidents. Acute intoxication also increases the risk of premature death, particularly drowning and traffic accidents. Epidemiological studies have demonstrated a lower risk of death from CHD among light and moderate drinkers as compared to abstainers (the J-shaped curve). These findings have induced an important debate concerning public health implications. At the aggregate level an increase in alcohol consumption has little impact on all-cause mortality, but changes in per capita consumption are found to covary significantly with deaths from alcohol related diseases, accidents and suicides.

Drug addicts are found to have a higher excess mortality than alcohol abusers (RR in the range of 5-30), and the most common causes of death are overdoses, suicides and accidents. On the other hand, use and abuse of alcohol is far more widespread in the population than narcotics, and most of the substance related deaths can thus be attributed to alcohol. To which degree this is reflected in the public opinion and in political strategies and allocation of resources, may however be questionned.

\section{INNLEDNING}

Dødelighet og dødsårsaker er hyppig anvendte indikatorer for helse, sykelighet, eller livskvalitet i en befolkning eller en befolkningsgruppe. En rekke studier har vist at både bruk og misbruk av ulike rusmidler øker dødeligheten, og at noen dødsårsaker er mer typiske ved rusmiddelbruk eller rusmiddelmisbruk. Vi skal i det følgende se litt nærmere på studier, og da fortrinnsvis fra vårt eget land og våre naboland, som har analysert sammenhenger mellom bruk og misbruk av ulike rusmidler og dødelighet. En oversiktspresentasjon over et såvidt bredt felt som dette må nødvendigvis gi et grovt og forenklet bilde, og mange tema og perspektiver er ikke tatt med.

Ved rusmiddelrelaterte dødsfall skiller vi gjerne mellom dødsfall knyttet til akutt beruselse og dødsfall blant kroniske misbrukere. Et slikt skille er ikke enty- 
dig eller enkelt operasjonaliserbart, men det er nyttig med hensyn på å skille mellom hovedgrupper av mekanismer for sammenhenger mellom rusmiddelbruk og dødelighet. Grovt forenklet kan vi si at den akutte beruselsen øker risikoen for dødsfall ved at man får redusert reaksjonsevne og koordineringsevne, men også svekket dømmekraft som bl.a. øker faren for trafikkulykker, fallulykker, drukning osv. Ved kronisk rusmiddelmisbruk vil organskader som følge av langvarig eksponering ha betydning for dødeligheten, og de sosiale følger av kronisk misbruk som sosial isolasjon, økonomi og arbeidslivstilknytning kan også påvirke dødeligheten.

Dødsfall ved akutt beruselse sees ofte blant personer som ikke har et misbruksproblem, men det sees også blant kroniske rusmiddelmisbrukere, og dødsfall som skyldes akutt forgiftning av alkohol eller overdose er mest typisk for misbrukere. Den forhøyete dødeligheten blant rusmiddelmisbrukere beskrives ofte som overdødelighet beregnet ved oppfølgingsstudier av utvalg av misbrukere fra behandlingsenheter men også fra fengsler. De fleste studier av dødelighet mht. rusmiddelbruk er knyttet til vårt vanligste rusmiddel; - alkohol, og til narkotika. Trolig er det også en sammenheng mellom dødelighet og misbruk av legemidler av beroligende typer (benzodiazepiner etc.), men på dette området finnes det få studier. Den følgende gjennomgangen av studier av rusmiddelbruk og dødelighet vil derfor være knyttet til alkohol og narkotika.

\section{ALKOHOL}

Det finnes en ganske bred forskningslitteratur på alkoholbruk og dødelighet og dødsårsaker, og vi skal i det følgende skille mellom studier på individnivå og studier på aggregert nivå. Skillet er ikke bare et uttrykk for ulike typer av empiriske tilnærminger, men studier av individuell risiko og studier av effekter på aggregert nivå har også ulik anvendbarhet. For det enkelte individ vil for eksempel spørsmålet om det finnes et konsumnivå som gir liten risiko for negative konsekvenser som sykelighet og dødelighet, være relevant. For alkoholpolitiske formål vil det på den annen side være viktig å kunne sammenholde alkoholkonsum og ulike konsekvenser av konsumet på et befolkningsnivå.

\section{Individnivåstudier}

\section{Dødelighet}

Det finnes ingen entydig definisjon av alkoholmisbruk, og det vil være ganske flytende overganger og betydelig grad av overlapping mellom begreper som høyt konsum, problemdrikking, alkoholmisbruk og alkoholavhengighet. De fleste studier av dødelighet og dødsårsaker blant alkoholmisbrukere er gjort blant utvalg av klienter eller pasienter ved behandlingsinstitusjoner for alkoholmisbruk eller alkoholproblemer. Studiene viser gjennomgående en forhøyet dødelighet blant alkoholmisbrukere, - i størrelsesorden 2 til 3. I Norge har Sundby (1) funnet en overdødelighet blant mannlige pasienter innlagt med alkoholdiagnoser i psykiatriske sykehus på 1,7. Rossow og Amundsen (2) fant i en 40-års oppfølging av vernepliktige på sesjon at menn som hadde vært innlagt eller innskrevet på behandlingsinstitusjon for alkoholmisbruk etter sesjon hadde en overdødelighet på 3,3, og at overdødeligheten økte med alder. Lindberg og Ågren (3) fant i en oppfølgingsstudie i Stockholm at klienter behandlet for alkoholproblemer hadde en overdødelighet på 3,0 . Thorarinsson (4) fant i sin studie fra Island en overdødelighet på 2,2, mens britiske studier har rapportert en overdødelighet blant mannlige alkoholmisbrukere på 2,7 (5) og 3,6 (6).

Slike estimater for dødelighet og overdødelighet betyr ikke nødvendigvis at et kronisk misbruk i seg selv forårsaker for tidlig dødsfall. Eksempelvis har vi i den norske oppfølgingsstudien av alkoholmisbrukere (2) funnet at noe av overdødeligheten er knyttet til lungekreft, hvilket trolig kan tilskrives den høye korrelasjonen mellom alkoholbruk og røyking.

\section{Risikokurver}

De som har et alkoholmisbruk og derved sannsynligvis et svært høyt alkoholkonsum har altså en betydelig forhøyet risiko for tidlig død. Men hvordan er risikoen for tidlig død ved lavere konsummengder? Er det en dose-respons relasjon mellom alkoholkonsum og dødelighet? En rekke studier på dette området har vært publisert, men mange av dem har vært kritisert for en del metodeproblemer; - bl.a. er det vanskelig å måle alkoholeksposisjon over tid, og mange relevante confoundere er ofte ikke tatt med i analysene (7).

For samlet dødelighet synes det å være en svakt Jformet sammenheng med alkoholkonsum, altså at de som har et lite eller meget moderat alkoholkonsum har en noe lavere risiko enn dem som ikke drikker alkohol, mens risikoen så igjen stiger med økende alkoholkonsum. Dette er funnet både for kvinner og menn (8-10). Ser vi på ulike grupper av dødsårsaker, finner vi imidlertid ulike former på risikokurvene. For dødsårsaker som levercirrhose og kreftformer i øvre deler av fordøyelsessystemet ser risikokurvene ut til å ha en tilnærmet eksponensiell funksjon, dvs. at det skjer en relativt liten eller ubetydelig risikoøkning ved lave alkoholinntak, mens risikoen så øker eksponensielt når alkoholinntaket blir høyt (7). For hjerte-karsykdommer synes risikokurven derimot å anta den såkalte J-form, og fordi hjerte-karsykdom er den desidert vanligste type dødsårsak, kan den svakt J-formete risikokurven for samlet dødelighet tilskrives den mer uttalte J-formete risikokurven for hjerte-karsykdom.

Alkoholberuselse påvirker kognisjon, persepsjon og motorikk og øker derved risikoen for ulykkes- 
dødsfall. En rekke studier har vist at risikoen for trafikkdødsfall øker med økende promillenivå. Denne økningen i relativ risiko er størst blant dem som drikker alkohol relativt sjelden (eksponensiell kurve), og økningen er minst blant dem som drikker alkohol daglig (lineær kurve) (kfr. 7). En 15 års oppfølgingsstudie av svenske rekrutter viste også en eksponensiell økning i risiko for voldsom død (ulykker, selvmord og drap) med økende alkoholkonsum, som igjen er høyt korrelert med beruselsesfrekvens (11).

\section{Dødsårsaker blant alkoholmisbrukere}

Et svært høyt alkoholkonsum eller et alkoholmisbruk reduserer levetiden og øker i særlig grad risikoen for å $\mathrm{d} ø$ av noen bestemte årsaker. Sundby (1) fant at overdødelighet blant alkoholmisbrukere i særlig grad var knyttet til tuberkulose, kreft i øvre deler av fordøyelseskanalen, ulykker, apopleksi, selvmord, andre kreftformer, hjerte-karsykdommer og ukjente dødsårsaker. Lindberg og Ågren (3) fant at overdødelighet blant alkoholmisbrukere var høyest mht. alkoholisme og alkoholforgiftning, levercirrhose, selvmord, pancreatitt og kreft i øvre deler av fordøyelseskanalen. Thorarinsson (4) fant høyest overdødelighet blant mannlige alkoholikere på Island av levercirrhose, alkoholisme, selvmord og ulykker. I en norsk oppfølgingsstudie av rekrutter fant Rossow og Amundsen (2) høyest overdødelighet blant alkoholmisbrukere som hadde vært i behandling mht. alkoholavhengighet, levercirrhose, drap, selvmord og ulykker. Dette illustrerer at overdødeligheten blant alkoholmisbrukere kan knyttes til flere typer av mekanismer. For det første ser vi at en del av overdødeligheten kan knyttes til de organskadene som skyldes den betydelige alkoholeksposisjonen som lever og øvre del av fordøyelseskanalen utsettes for gjennom et langvarig misbruk. For det andre kan også overdødelighet hos kroniske misbrukere knyttes til følgene av akutt beruselse som ved alkoholforgiftninger og andre ulykker. Skullerud og medarbeidere (12) fant eksempelvis at ved de fleste ulykkesdødsfall blant alkoholikere var promillen på over 0,5 . Når det gjelder overdødelighet ved selvmord kan både det kroniske alkoholmisbruket og den akutte beruselsen spille en rolle. Delvis kan man tenke seg at det skjer en viss seleksjon til alkoholmisbruk og at personer med større selvmordstilbøyelighet (eksempelvis ved en primær depresjon) også har en større tilbøyelighet til alkoholmisbruk. Blant alkoholmisbrukere som tar sitt eget liv, finner man ofte indikasjoner på tidlige depresjoner eller annen psykiatrisk komorbiditet (13). Det kroniske misbruket fører imidlertid også ofte til en sekundær depresjon eller en forsterkning av en depressiv tilstand, og et kronisk misbruk innebærer også ofte en økende grad av sosial disintegrering og isolasjon. Derved kan misbruket også være en årsak til selvmord (14). Alkoholberuselse kan også spille en rolle ved at rusen kan forsterke depressive tilstander og redusere hemninger mot å påføre seg selv skade.

Selv om alkoholmisbrukere har en særlig høy overdødelighet av noen typer sykdommer og skader, vil allikevel de vanligste dødsårsaker som hjertekarsykdommer, kreft og ulykker også være de mest utbredte dødsårsaker blant alkoholmisbrukere (2-6).

\section{Andeler av dødsfall som kan tilskrives alkoholberuselse}

Det er i særlig grad ved brå dødsfall som ulykker, selvmord og drap at alkoholberuselse har betydning. I en rettsmedisinsk undersøkelse av middelaldrende menn som døde utenfor institusjon fant Skullerud og medarbeidere (12) at blant dem som døde ved ulykke, selvmord eller drap hadde halvparten (63 av 127) en promille på 0,5 eller mere. Arner (15) fant $\mathrm{i}$ en studie av dødsulykker blant sjømenn at alkohol hadde spilt en rolle $\mathrm{i}$ en tredel av alle ulykkestilfellene, og oftere ved forgiftningsulykker (60\%), drukningsulykker (48\%) og ved drap (47\%). Blant bilførere som har vært innblandet i trafikkulykker har man funnet at $42 \%$ av dem som var innblandet i eneulykker (ett kjøretøy involvert) var beruset på alkohol, enten alkohol alene $(33 \%)$ eller sammen med medikamenter/ narkotika (9\%) (16).

Ved selvmord finner man også høye andeler med alkoholberuselse. I en studie av selvmord blant unge i Oslo fant Retterstøl og medarbeidere (17) at halvparten (av de obduserte) var påvirket av alkohol og/eller avhengighetsskapende stoffer.

\section{Studier på aggregert nivå}

Dødelighet kan være ett mål for kostnader ved alkoholkonsumet $i$ en befolkning. Hvor mye et bestemt alkoholkonsumnivå eller hvor mye en endring $i$ konsumnivået koster oss i dødsfall, vil derfor være alkoholpolitisk viktig og relevant.

Empiriske studier fra en rekke land med ulike alkoholkulturer har vist at en økning i gjennomsnittskonsumet $\mathrm{i}$ en befolkning er et resultat av at både de med et lavt, de med et middels og de med et høyt alkoholkonsum har økt alkoholinntaket (18-20). Omvendt kan vi derfor si at andelen av alkoholmisbrukere eller alkoholavhengige i en befolkning i stor grad avhenger av hvor mye alkohol som drikkes i gjennomsnitt i denne befolkningen. Dersom gjennomsnittskonsumet i en befolkning øker til det dobbelte, vil andelen misbrukere øke til det firedobbelte (19). Videre innebærer også en økning i gjennomsnittskonsumet ikke bare at antall drikketilfeller øker, men også at alkoholinntak per drikketilfelle øker (7). Det kan derfor gi mening $\mathrm{i}$ å studere effekten av endringer $i$ alkoholkonsumet $i$ en befolkning med hensyn på helsemessige eller sosiale konsekvenser på et aggregert nivå. Slike studier på aggregert nivå er stort 
sett enten tverrsnittsanalyser med sammenlikninger mellom ulike populasjoner (økologiske korrelasjoner), eller tidsserieanalyser innenfor samme populasjon. Vi skal i det følgende vise til noen resultater fra slike studier av alkoholkonsum og dødelighet på aggregert nivå, både med hensyn til total dødelighet og årsaksspesifikk dødelighet.

\section{Endringer $i$ dødelighet med endring i per capita- konsumet}

Analyser av data fra Frankrike, Preussen og Sverige har vist at en økning i det årlige alkoholkonsumet på en liter ren alkohol per innbygger over 15 år, innebærer en økning i den samlete dødeligheten blant middelaldrende menn på omkring 1\% (7). Selv en vesentlig økning i alkoholkonsumet vil altså ikke gi betydelige endringer i den samlete dødeligheten.

Derimot vil endringer i gjennomsnittskonsumet bli mer tydelig for dødsårsaker hvor alkohol er en kjent risikofaktor. Tidsserieanalyser av alkoholkonsum og levercirrhose har vist en klar sammenheng mellom gjennomsnittskonsum og cirrhosedødelighet, men effekten fordeles over flere tiår. Dette henger sammen med at det å dø av skrumplever stort sett skjer etter mange år med et svært høyt alkoholkonsum. Det er likevel interessant at man i slike tidsserieanalyser også ser en umiddelbar effekt av endring i alkoholkonsumet på cirrhosedødeligheten (ca. 1/5 av effekten sees samme år eller året etter en konsumendring $\mathrm{i}$ befolkningen) og halvparten av effekten kan sees i løpet av en fire-års periode etter en endring i befolkningens konsum (21-22). Ledermann (23) viste også at da alkohol ble rasjonert i Paris i 1942 (rasjonene var på 0,5 til 1 liter vin per person per uke), ble gjennomsnittskonsumet redusert med minst $80 \%$, og året etter var cirrhosedødeligheten redusert med 50\%. Vi ser altså at endringer i per capita-konsumet kan gi umiddelbare effekter i dødelighetsnivå også for tilstander som utvikles gjennom lang tids alkoholeksponering.

Tilsvarende er det også funnet klare sammenhenger mellom alkoholkonsum og dødelighet av alkoholrelaterte sykdommer som kreft i lepper, munnhule, svelg og spiserør, alkoholpsykose, alkoholavhengighet, pankreatitt og alkoholforgiftning (24). En liters økning i gjennomsnittlig alkoholkonsum per innbygger per år, vil gi en økning i dødsfall i alkoholrelaterte sykdommer på omtrent $18 \%$ for menn og $7 \%$ for kvinner (25). De ulike effektmålene for menn og kvinner henger sammen med at menn står for størstedelen av gjennomsnittskonsumet og har en vesentlig større andel høykonsumenter eller misbrukere. Tilsvarende ser vi også høyere effektmål for menn enn for kvinner ved analyser på aggregert nivå av andre grupper av dødsårsaker og gjennomsnittlig alkoholkonsum. Dette knytter seg til at menn både står for en høyere andel av høykonsumenter eller misbrukere enn kvinner, og også at menn står for en større andel av drikketilfellene og beruselsestilfellene enn kvinner.

Det er etter hvert også foretatt en rekke studier av sammenhenger mellom alkoholkonsum og selvmord på aggregert nivå. Disse viser en signifikant sammenheng mellom endringer i konsumnivå og selvmordsrater for menn. En interessant observasjon her er at effekten av en økning i gjennomsnittskonsumet med 1 liter per innbygger per år, synes å være størst i land med et lavt konsumnivå ("tørre" kulturer), og for Sverige og Norge har man beregnet at en slik økning $i$ konsumet vil være assosiert med en økning i selvmordsraten for menn i størrelsesorden $10-15 \%$ $(26,27)$. I land med et relativt høyt alkoholkonsum ("våte" kulturer) som Frankrike og Portugal, gir imidlertid en slik økning i alkoholkonsumet et relativt mindre utslag på selvmordstallene (størrelsesorden 23\%) (28-29).

Gjennomsnittskonsumet er også vist å henge sammen med dødsulykker (med unntak av arbeidsulykker hvor alkohol sjelden er involvert) (30), og en økning med 1 liter ren alkohol i gjennomsnittskonsumet per innbygger per år vil gi en økning i dødsulykker på omtrent $8 \%$ for menn og 3\% for kvinner (25). Tilsvarende har man beregnet at en økning på 1 liter $i$ gjennomsnittskonsumet vil gi en økning i antallet drepte på $11 \%$ per år (25).

Disse anslagene har også vært brukt i en rapport om vurdering av konsekvenser av ulike endringer $\mathrm{i}$ omsetningsform og priser for alkohol i Norge (25). Kostnader, i form av dødelighet, ved en økning i alkoholkonsumet har her vært knyttet til betydning av prisnivå og privatisert omsetning av vin og brennevin, og inngår som argumenter $\mathrm{i}$ debatten om bruk av alkoholpolitiske virkemidler som omsetningsformer og priser.

\section{NARKOTIKA}

\section{Dodelighet og forhoyet dodelighet blant stoffmisbrukere}

Stoffmisbrukere har en høy dødelighet, og mange dør i ganske ung alder. Beregnet overdødelighet blant stoffmisbrukere er i størrelsesorden fra 5 til 30 (altså 5 til 30 ganger høyere dødelighet enn i befolkningen ellers) (31-33). Norske studier av stoffmisbrukere viser at dødeligheten ligger på ca. $2 \%$ per år, dvs. at 2 av 100 stoffmisbrukere vil dø i løpet av ett år (32-33). Mannlige stoffmisbrukere synes å ha en noe høyere dødelighet enn kvinnelige, mens i befolkningen generelt finner vi at dødeligheten er dobbelt så høy blant unge menn (25-44 år) som blant unge kvinner. Derved blir overdødeligheten blant kvinnelige stoffmisbrukere høyere enn blant mannlige stoffmisbrukere (31-33). 


\section{Dødsårsaker blant stoffmisbrukere}

Den høye dødeligheten blant stoffmisbrukere betyr også at mange stoffmisbrukere dør i relativt ung alder. Når unge mennesker dør, skjer det oftest brått. Av dødsårsaksstatistikken for hele befolkningen fra 1992 ser vi at nesten halvparten av dødsfallene blant menn i aldersgruppen 25-44 år skyldtes ulykker, selvmord eller drap, - i det alt vesentlige de to førstnevnte, mens en fjerdedel av dødsfallene blant kvinner i denne aldersgruppen skyldtes ulykker, selvmord eller drap. I aldersgruppen 10-24 år er andelen brå dødsfall enda større.

Brå dødsfall er imidlertid enda mer vanlig blant stoffmisbrukere enn blant unge i befolkningen generelt. Eskild og medarbeidere (32) fant i en oppfølgingsstudie av HIV-testete intravenøse stoffmisbrukere at $58(67 \%)$ av de 87 som døde døde av overdose, $9(10 \%)$ døde ved selvmord, 6 personer døde av ulike sykdommer (hvorav 4 døde av AIDS), 4 ble drept og 4 døde ved ulykker.

En oppfølgingsstudie av stoffmisbrukere som hadde vært i behandling (33) viste også at en stor andel (81 av 287, dvs. 28\%) av dødsfallene blant misbrukerne skjedde ved overdoser, $21 \%$ av dødsfallene var selvmord, $17 \%$ skyldtes ulykker og drap, mens $16 \%$ skyldtes sykdommer.

Også en oppfølgingsstudie av stoffmisbrukere i Sverige gir et tilsvarende bilde mht. fordelinger av dødsårsaker. Tunving (31) fant $\mathrm{i}$ en studie av stoffmisbrukere i Lund at 35 av 62 dødsfall (56\%) skyldtes overdose og 19 (31\%) skyldtes selvmord. De resterende dødsfallene skyldtes ulykker og vold, og det var ingen dødsfall som skyldtes sykdommer.

Det er altså noen ulikheter i fordeling av dødsårsaker i disse tre studiene, noe som blant annet kan skyldes forskjeller i utvalg av stoffmisbrukere og oppfølgingstid. Men, i alle tre studier finner en at brå dødsfall er typisk for stoffmisbrukere; - de langt fleste dødsfallene i denne gruppen skjer ved overdose og ved selvmord, i noen grad også ved ulykker eller drap.

Narkotikadødsfall er en betegnelse på dødsfall blant stoffmisbrukere som er knyttet til utilsiktet virkning av illegale narkotiske stoff eller skjulte selvmord hvor narkotika er brukt i den hensikt å ta sitt eget liv (34). Dette vil altså i stor grad dreie seg om overdoser og, som vi ser, utgjør de en betydelig andel av dødsfallene blant stoffmisbrukere. Omfanget av narkotikadødsfall brukes blant annet som en indikator på narkotikasituasjonen og/eller som en indikator på dødeligheten blant stoffmisbrukere ved sammenlikninger mellom regioner eller land. I Norge har det vært en liten økning i antall narkotikadødsfall gjennom 1980tallet, mens det har skjedd en fordobling $\mathrm{i}$ antall narkotikadødsfall fra 1989 til 1993 (SSB, dødsårsaksstatistikken). Bretteville-Jensen (34) viser imidlertid at denne økningen ikke er et uttrykk for at antallet personer med et tyngre narkotikamisbruk har økt.
Derimot synes økningen i antall narkotikadødsfall å henge sammen med andre forhold som økende alder blant misbrukerne, større grad av blandingsmisbruk med bl.a. Rohypnol, et betydelig prisfall på heroin og dermed økt forbruk for den enkelte misbruker, samt at det trolig har vært en økning $\mathrm{i}$ antall institusjonsopphold (i fengsler og behandlingsinstitusjoner) med påfølgende senket toleranse for heroin og derved økt fare for overdosedødsfall (34).

\section{NOEN AVSLUTTENDE BETRAKTNINGER}

Vi har i det foregående sett på dødsfall som er knyttet til eget rusmiddelbruk, men det er selvfølgelig også en del dødsfall som skyldes andres rusmiddelbruk eller misbruk, eksempelvis ofre for promillekjøring eller berusete drapsmenn. Disse dødsfallene utgjør en mindre andel av alle rusmiddelrelaterte dødsfall, men som rusmiddelpolitisk argument vil slike dødsfall veie tungt, fordi en del av kostnadene ved rusmiddelbruken i samfunnet bæres av "uskyldige" parter.

Det vil av det foregående framgå at dødeligheten og overdødeligheten ved stoffmisbruk er vesentlig større enn ved alkoholmisbruk. På den annen side er alkoholbruk og alkoholmisbruk av et vesentlig større omfang i befolkningen enn stoffmisbruk, slik at omfanget av alkoholrelaterte dødsfall blir betydelig større enn omfanget av narkotikarelaterte dødsfall. Eksempelvis ser vi av dødsårsaksstatistikken for perioden 1988-1992 at antallet dødsfall som kunne tilskrives alkoholmisbruk var 7 ganger høyere enn antall dødsfall som kunne tilskrives narkotikamisbruk (35). Fekjær (36) har beregnet at mellom $1200 \mathrm{og}$ 1800 dødsfall per år skyldes rusmiddelbruk, hvorav 1100-1700 skyldes alkoholbruk. Målt i dødelighet har altså alkoholmisbruk større samfunnsmessige kostnader enn narkotikamisbruk. Men hvilke konsekvenser får dette?

Dødelighet knyttet til rusmiddelbruk og rusmiddelmisbruk er ikke bare en viktig indikator for helse og sykelighet og som sådan et viktig redskap for monitoreringsformål innenfor helse- og omsorgstjenesten. Dødelighet ser også ut til å kunne være et viktig argument i politiske prosesser og for politiske prioriteringer av ressurser. Men, argumentet synes å ha ulik gyldighet eller relevans for ulike rusmidler. Eksempelvis ble narkotikadødeligheten et eksplisitt argument for økete bevilgninger til behandling av stoffmisbrukere i Oslo høsten 1995. Tilsvarende argumenter synes imidlertid ikke å komme i betraktning med hensyn på tiltak overfor alkoholmisbrukere. En forklaring på dette kan tenkes å henge sammen med at narkotikaproblemet oppfattes i befolkningen som vesentlig større enn alkoholproblemet. Valberg (37) fant at medias omtale av alkohol og narkotika var vesensforskjellig i mange henseender: valg av fokus, 
problematisering, bruk av verdiladete ord osv. bidrar til å skape et bilde av narkotika som et stort og alvorlig problem, mens alkohol oftest framstilles utenfor noen problemsammenhenger. I tråd med dette fant han også at medias fokusering på rusmiddelrelaterte dødsfall varierte betydelig: narkotikadødsfall får fete overskrifter og bred omtale, mens alkoholdødsfall ikke (eller i meget beskjeden grad) omtales i media. Intervjuundersøkelser i befolkningen viser også at antallet dødsfall som tilskrives alkoholbruk undervurderes, mens dødsfall som tilskrives narkotikabruk overvurderes (38). Derved kan ressursprioriteringer overfor stoffmisbrukere tenkes å ha mer støtte i opinionen og større politisk legitimitet. Dessuten kan man anta at måten alkohol og narkotika framstilles på i media, både med hensyn på bruk og konsekvenser, ikke bare har betydning for de antakelser og holdninger man finner $\mathrm{i}$ befolkningen generelt, men også for de argumenter som føres fram i de politiske debattene og beslutningsprosessene.

La oss helt til slutt se på et meget aktuelt og hyppig debattert tema innenfor alkoholforskningen; nemlig folkehelseaspektene ved funnene fra epidemiologiske studier som viser en J-formet kurve for alkoholbruk og dødelighet ved hjerte-karsykdommer (jfr. artikkel av Inger Stensvold i dette nummeret). Dersom det er slik at den J-formete kurven virkelig skyldes en gunstig effekt av et lavt eller meget moderat alkoholkonsum og ikke kan tilskrives en seleksjonseffekt, hvilke implikasjoner har dette i en folkehelsesammenheng? For det første innebærer den lange høyresidige halen i fordelingen av alkoholkonsumet at det konsumnivået som er optimalt for enkeltindividet, er vesentlig høyere enn det optimale gjennomsnittskonsumet i befolkningen (39). I de fleste vestlige industrialiserte land ligger allerede gjennom- snittskonsumet godt over det konsumnivået som på basis av den J-formete kurven antas å gi den laveste mortalitetsrisiko (40). Dessuten må man spørre seg hva konsekvensene ville være dersom man formidlet et helsebudskap til befolkningen om at et moderat alkoholkonsum er gunstig mht. hjerte-karsykdommer (41). Dersom effekten ble at de som var avholdende eller meget måteholdne begynte å drikke litt eller litt mer, mens de som allerede drakk mye reduserte sitt forbruk til et antatt optimalt nivå, så ville trolig dødeligheten ved hjerte-karsykdommer gå ned. Men en slik effekt er neppe realistisk. Tvertimot er det god grunn til å anta at dersom en betydelig andel av befolkningen (de som drikker lite eller ingenting) begynner å drikke mere, så vil det skapes flere drikkesituasjoner og flere anledninger eller incitamenter for å drikke mere også for den delen av befolkningen som allerede drikker for mye (41). Den samlete effekten vil altså være at alle grupper i befolkningen drikker mere, og gjennomsnittskonsumet øker. Den gevinsten som ligger i en redusert dødelighet blant dem som i utgangspunktet drakk lite eller ingenting vil derved mer enn kompenseres ved den økete dødeligheten blant dem som i utgangspunktet drakk for mye.

Debatter som denne er viktige og nyttige i mange henseender: ett aspekt er naturligvis de metodologiske og substansielle diskusjonene som føres i fagmiljøene med hensyn på kausalitet og som alltid vil være viktig i forhold til epidemiologiske studier. Men debatten illustrerer også et annet viktig aspekt ved mye epidemiologisk forskning: nemlig hvilke implikasjoner får funnene våre $i$ en folkehelsesammenheng? Innenfor epidemiologisk forskning vil det derfor være viktig å både erkjenne og ta de utfordingene som ligger $\mathrm{i}$ å nærme seg slike spørsmål og sette dem i sammenheng med egen forskning.

\section{REFERANSER}

1. Sundby P. Alcoholism and mortality. Oslo: Universitetsforlaget, 1967.

2. Rossow I, Amundsen A. Alcohol abuse and mortality; a 40 year prospective study of Norwegian conscripts. Social Science and Medicine: submitted.

3. Lindberg S, Ågren G. Mortality among male and female hospitalized alcoholics in Stockholm 1962-1983. British Journal of Addiction 1988; 83: 1193-1200.

4. Thorarinsson AA. Mortality among men alcoholics in Iceland, 1951-74. Journal of Studies on Alcohol 1979; 40: 704-718.

5. Edwards G, Kyle E, Nicholls P, Taylor C. Alcoholism and mortality. Implications for epidemiology. Journal of Studies on Alcohol 1978; 39: 1607-1617.

6. Marshall EJ, Edwards G, Taylor C. Mortality in men with drinking problems: a 20-year follow-up. Addiction 1994; 89: 1293-1298.

7. Edwards G, Anderson P, Babor TF, Casswell S, Ferrence R, Giesbrecht N, Godfrey C, Holder HH, Lemmens P, Mäkelä K, Midanik LT, Norström T, Österberg E, Romelsjö A, Room R, Simpura J, Skog OJ. Alcohol Policy and the Public Good. Oxford: Oxford University Press, 1994.

8. Rehm J, Sempos CT. Alcohol consumption and all-cause mortality. Addiction 1995; 90: 471-480. 
9. Shaper AG, Wannamethee G, Walker M. Alcohol and mortality in British men: explaining the U-shaped curve. Lancet 1988; ii: 1267-1273.

10. Fuchs CS, Stampfer MJ, Colditz GA, Giovannucci EL, Manson JE, Kawachi I, Hunter DJ, Hankinson SE, Hennekens CH, Rosner B, Speizer FE, Willett WC. Alcohol consumption and mortality among women. New England Journal of Medicine 1995; 19: 1245-1250.

11. Andreasson S, Romelsjö A, Allebeck P. Alcohol and mortality among young men: longitudinal study of Swedish conscripts. British Medical Journal 1988; 296: 1021-1025.

12. Skullerud K, Andersen SN, Olving JH. Alkohol og dødsårsaksstatistikken for middelaldrende menn i Oslo. Tidsskrift for Den Norske Laegeforening 1990; 110: 1366-1371.

13. Murphy GE. Suicide in Alcoholism. New York: Oxford University Press, 1992.

14. Skog O-J. Alcohol and suicide - Durkheim revisited Acta Sociologica 1991; 34: 193-206.

15. Arner O. Dødsulykker blant sjømenn. Oslo: Universitetsforlaget, 1970.

16. Rusmiddeldirektoratet og Transportøkonomisk institutt. Ruspåvirket kjøring og ruspåvirkete førere. Oslo: Rusmiddeldirektoratet, 1986.

17. Retterstøl N, Gjertsen F, Ekeland H, Olving JH. Selvmord blant unge i alderen 15-29 år i Oslo. Tidsskrift for Den Norske Laegeforening 1993; 113: 1969-1974.

18. Bruun K, Edwards G, Lumio M, Mäkelä K, Pan L, Popham RE, et al. Alcohol Control Policies in Public Health Perspective. Helsinki: The Finnish Foundation for Alcohol Studies, 1975.

19. Skog O-J. The collectivity of drinking cultures. A theory of the distribution of alcohol consumption. British Journal of Addiction 1985; 80: 83-99.

20. Lemmens P, Tan E, Knibbe R. Comparing distributions of alcohol consumption: empirical probability plots. British Journal of Addiction 1990; 85: 751-758.

21. Skog O-J. The risk function of liver cirrhosis from life time alcohol consumption. Journal of Studies on Alcohol 1984; 45: 199-208.

22. Norström T. The impact of per capita consumption on Swedish cirrhosis mortality. British Journal of Addiction 1987; 82: 67-75.

23. Ledermann S. Alcool, Alcoolism, Alcoolisation, Vol. 2. Paris: Presses Universitaires de France, 1964.

24. Skog O-J. Trends in alcohol consumption and deaths from diseases. Bristish Journal of Addiction 1987; 82: 1033-1041.

25. Skog O-J, Horverak Ø, Nordlund S, Norström T. Vurdering av konsekvenser av ulike endringer i omsetningsform og priser for alkohol i Norge. Oslo: Statens institutt for alkohol- og narkotikaforskning, 1993.

26. Norström T. Alcohol and suicide in Scandinavia British Journal of Addiction 1988; 83: 553-559.

27. Rossow I. Suicide, alcohol and divorce; aspects of gender and family integration Addiction 1993; 88: 16591665 .

28. Norström T. Alcohol and suicide: a comparative analysis of France and Sweden Addiction 1995; 90: 14631469.

29. Skog O-J, Teixeira Z, Barrias J, Moreira R. Alcohol and suicide - the Portuguese experience. Addiction 1995; 90: 1053-1061.

30. Skog O-J. Trends in alcohol consumption and violent deaths. British Journal of Addiction 1986; 81: 365-379.

31. Tunving K. Fatal outcome in drug addiction. Acta Psychiatrica Scandinavia 1988; 77: 551-556.

32. Eskild A, Magnus P, Samuelsen SO, Sohlberg C, Kittelsen P. Dødelighet og dødsårsaker blant intravenøse stoffmisbrukere i Oslo. Tidsskrift for Den Norske Laegeforening 1993; 113: 1331-1333.

33. Rossow I, Kielland K. Dødelighet blant stoffmisbrukere i Norge. Tidsskrift for Den Norske Lageforening 1995; 115: 1050-1054.

34. Bretteville-Jensen AL. Narkotikadødsfall i Norge. En analyse av utviklingen fra 1976-1993. Oslo: Statens institutt for alkohol- og narkotikaforskning, 1994.

35. Grytten L (red.). Rusmidler i Norge. 1995. Oslo: Rusmiddeldirektoratet og Statens institutt for alkohol- og narkotikaforskning, 1995.

36. Fekjær HO. Alkohol og narkotika - myter og virkelighet. Oslo: Gyldendal, 1987. 
37. Valberg A. Norsk presses fremstilling av rusmidler og rusmiddelbrukere: Samfunnsspeil eller desinformasjon? I: Waal H, Middelthon A-L, red. Narkotikaforebygging mot år 2000. Oslo: Universitetsforlaget, 1992: 227-243.

38. Baklien B. Aksjon mot rusmidler. Evalueringsrapport. Oslo: Rusmiddeldirektoratet og Statens institutt for alkohol- og narkotikaforskning, 1988.

39. Lemmens PH. Drinking for health: balancing individual risk and public health hazards. Contemporary Drug Problems 1994; 251-271.

40. Anderson P. Alcohol consumption and all-cause mortality. Comment on Rehm \& Sempo's “Alcohol consumption and all-cause mortality“. Addiction 1995; 90: 481-484.

41. Skog O-J. The J-curve, causality and public health. Comment on Rehm \& Sempo's “Alcohol consumption and all-cause mortality“. Addiction 1995; 90: 490-492. 